\title{
K-Based Geopolymer from metakaolin: roles of K/Al ratio and water or steam Curing at different temperatures
}

\author{
A. Tawfik ${ }^{\mathrm{a}} \bowtie$, F. Abd El-Raoof ${ }^{\mathrm{a}}$, H. Katsuki ${ }^{\mathrm{b}}$, K.J.D. MacKenzie ${ }^{\mathrm{c}}$, S. Komarneni ${ }^{\mathrm{d}}$ \\ a. Department of Refractories, Ceramics and Building materials, National Research Center (Cairo, Egypt) \\ b. Saga Ceramics Research Laboratory (Saga, Japan) \\ c. MacDiarmid Institute for Advanced Materials and Nanotechnology, Victoria University of Wellington, (Wellington, New Zealand) \\ d. Materials Research Institute and Department of Ecosystem Science and Management, \\ The Pennsylvania State University (University Park, USA) \\ $\triangle$ tawfik_omar76@yahoo.com
}

Received 19 April 2015 Accepted 14 September 2015 Available on line 15 March 2016

\begin{abstract}
K-based geopolymer binder was prepared by reacting metakaolin with alkaline solutions having different potassium contents and by water curing at room temperature and $80{ }^{\circ} \mathrm{C}$ as well as steam curing at 150 and $180{ }^{\circ} \mathrm{C}$. The phase formation, microstructure and $\mathrm{Al}$ and Si nearest neighbor environments were studied using XRD, TEM and ${ }^{27} \mathrm{Al}$ and ${ }^{29} \mathrm{Si}$ MAS NMR spectroscopy, respectively. The results revealed that amorphous alumino-silicates were predominant in geopolymer prepared by curing up to 28 days at room temperature or at $80^{\circ} \mathrm{C}$. The amorphous alumino-silicates persisted after hydrothermal treatment at $150{ }^{\circ} \mathrm{C} / 48 \mathrm{hrs}$ and even at $180^{\circ} \mathrm{C} / 30 \mathrm{hrs}$. However, the samples cured hydrothermally at $180^{\circ} \mathrm{C} / 48$ hrs revealed formation of crystalline potassium aluminum silicate and chabazite phases. The $\mathrm{Al}$ nearest neighbor environments was not significantly affected by increasing the K/Al ratio up to 1.55 or by the curing temperatures. On the other hand, the geopolymer reaction appears to have increased when cured at $80^{\circ} \mathrm{C}$ or steam cured at $150^{\circ}$ and $180^{\circ} \mathrm{C}$ and crystalline aluminosilicates resulted when the geopolymer sample was hydrothermally treated at $180^{\circ} \mathrm{C} / 48 \mathrm{hrs}$.
\end{abstract}

KEYWORDS: K-based geopolymer; Steam curing; Microstructure; NMR

Citation/Citar como: Tawfik, A.; Abd El-Raoof, F.; MacKenzie, K.J.D.; Komarneni, S. (2016) K-Based Geopolymer from Metakaolin: Roles of K/Al Ratio and Water or Steam Curing at Different Temperatures Mater. Construcc. 66 [322], e081. http://dx.doi.org/10.3989/mc.2016.03115.

RESUMEN: Geopolímeros de metakaolin basados en potasio: papel de la relación K/Al y del curado en agua o con vapor a diferentes temperaturas. Se prepararon geopolímeros por reacción de metacaolín con disoluciones alcalinas con diferentes contenidos de potasio. Se realizó un curado con agua a temperatura ambiente y a $80^{\circ} \mathrm{C}$, y con vapor de agua a 150 y $180^{\circ} \mathrm{C}$. La formación de las diferentes fases así como la microestructura y entornos del Al y Si se estudiaron mediante DRX, TEM y espectroscopia de RMN MAS de ${ }^{27} \mathrm{Al}$ y ${ }^{29} \mathrm{Si}$. Los aluminosilicatos amorfos fueron predominantes en aquellos geopolímeros sometidos a curado de hasta 28 días a temperatura ambiente o a $80^{\circ} \mathrm{C}$. Los aluminosilicatos amorfos persistieron tras el tratamiento hidrotermal a $150{ }^{\circ} \mathrm{C} / 48$ horas e incluso a $180{ }^{\circ} \mathrm{C} / 30 \mathrm{~h}$. Sin embargo, las muestras curadas hidrotermalmente a $180{ }^{\circ} \mathrm{C} / 48 \mathrm{~h}$ revelaron la formación de fases cristalinas de silicatos de aluminio y potasio, así como de chabazita. Los entornos de $\mathrm{Al}$ no resultaron afectados significativamente por el aumento de la relación $\mathrm{K} / \mathrm{Al}$ de hasta 1.55, ni por las temperaturas de curado. Por otro lado, la reacción de geopolimerización aumentó cuando el curado se realizó a $80^{\circ} \mathrm{C}$ o con curado a vapor a 150 y $180^{\circ} \mathrm{C}$.

PALABRAS CLAVE: Geopolímero basado en potasio; Curado con vapor; Distribución de tamaño de partículas; Resonancia Magnética Nuclear (RMN)

Copyright: (C) 2016 CSIC. This is an open-access article distributed under the terms of the Creative Commons Attribution-Non Commercial (by-nc) Spain 3.0 License. 


\section{INTRODUCTION}

Geopolymers are inorganic binders with good resistance to high temperatures and acid degradation, as well as good mechanical properties (1). Therefore, they are an attractive alternative to standard Portland cement, and their use allows for the recycling of large amounts of industrial waste. The mechanical properties of geopolymer materials were shown to depend on (a) the alkali cations $(\mathrm{Na}+$ or $\mathrm{K}+)$ and (b) the $\mathrm{Si} / \mathrm{Al}$ molar ratio (2). The compressive strengths of potassium-based geopolymers were found to be greater than those of sodium based materials, when their Si/Al molar ratios were between 1.4 and 1.9 (2). However, at higher Si/Al ratios $(\sim 2.15)$ a decrease in mechanical properties was observed due to the presence of unreacted cations after polycondensation reactions had occurred (2). The working properties of these materials were also found to depend on the amount of water added to the mixtures (3). Trapped water in the geopolymer network generates porosity, which results in diminished mechanical properties. The term "geopolymer" is based on the amorphous nature of these materials and the coordination environments of silicon and aluminum. Their three-dimensional structure is composed of $\mathrm{SiO}_{4}$ and $\mathrm{MAlO}_{4}$ tetrahedra, where $\mathrm{M}$ is a monovalent cation, typically $\mathrm{Na}^{+}$or $\mathrm{K}^{+}$. The geopolymer network is comparable to that of some zeolites but it differs from zeolites in that the network in geopolymers are randomly arranged, giving them an X-ray amorphous character. The polymeric character of these materials increases with the $\mathrm{Si} / \mathrm{Al}$ ratio, as the aluminum atoms cross-link with the chains of $\mathrm{SiO}_{4}$ tetrahedra. In general, their chemical composition is of the form $\left\{\mathrm{M}+\mathrm{n}\left(\mathrm{SiO}_{2}\right) \mathrm{z}, \mathrm{AlO}_{2}\right\} \mathrm{n}, \mathrm{w} \mathrm{H}_{2} \mathrm{O}$, where $\mathrm{z}$ is the $\mathrm{Si} / \mathrm{Al}$ molar ratio, $\mathrm{M}^{+}$is the monovalent cation and $\mathrm{n}$ is the polymerization degree (1). Thus, altering the $\mathrm{Si} / \mathrm{Al}$ ratio in geopolymers allows the synthesis of materials with different structures. The geopolymerization mechanism is particularly difficult to study on account of the slow reaction kinetics and the amorphous character of the products. However, most authors agree that the mechanism involves dissolution, followed by gel polycondensation $(4,5)$.

Some studies have been made of the curing of geopolymer materials at different temperatures to provide useful information about the reaction mechanism as a function of curing temperature. Among the different geopolymer materials, metakolin- and fly ash- based geopolymers activated by alkali were found to have an optimum curing temperature in air of $60^{\circ} \mathrm{C}(6,7)$. However when these geopolymer samples were cured at temperatures $>60{ }^{\circ} \mathrm{C}$, the compressive strength decreased (7). Based on the current knowledge of geopolymers, the facile preparation procedure for a chemically stable metakaolin geopolymer can be summarized as follows: setting and curing of the reagents (a solid aluminosilicate source and an alkali silicate solution) occurs at room temperature in a mould which provides a moisture level of about $40 \%$ (8). However, curing at $50{ }^{\circ} \mathrm{C}$ was reported not to lead to improved properties compared to room temperature curing, but curing at $110^{\circ} \mathrm{C}$ produced a really stable matrix of a semicrystalline nature, which was more zeolite-like (8). Although the effect of temperature in controlling the reactions is understood in metakaolin geopolymers to some extent, more research is needed about the various factors that control the geopolymer-forming reactions. For this reason, the present study is focused on the effect of the potassium content on metakaolin-geopolymer samples when they are cured in water at room temperature and at $80^{\circ} \mathrm{C}$. The effect of steam curing of selected geopolymer samples was also determined. The geopolymerization reaction of cured samples was stopped at different times and the product phases were characterized using XRD, TEM, ${ }^{29} \mathrm{Si}$ and ${ }^{27} \mathrm{Al}$ MAS NMR spectroscopy to provide a deeper understanding of the reactions involved.

\section{MATERIALS AND METHODS}

\subsection{Raw materials}

The starting materials were commercial, highly reactive metakaolin (HRM) supplied by Advanced Cement Technology, Blaine WA, USA $\left(\mathrm{SiO}_{2}=51.74 \mathrm{wt} \%\right.$, $\left.\mathrm{Al}_{2} \mathrm{O}_{3}=42.79 \mathrm{wt} \%\right)$, potassium silicate powder $\left(\mathrm{SiO}_{2} /\right.$ $\mathrm{K}_{2} \mathrm{O}=1.63$ ) supplied by $\mathrm{PQ}$ Corporation Industrial Chemicals Division, PA, USA and Potassium hydroxide ACS grade (purity $=86.27 \%$ ) supplied by Fisher Scientific.

\subsection{Sample preparation}

The potassium hydroxide and potassium silicate were dissolved in a predetermined amount of water to produce a clear solution. The metakaolin powder was then mixed with the prepared alkaline solution at room temperature according to the sample compositions shown in Table 1. These compositions were achieved by varying the $\mathrm{KOH}$ molarity to give K/Al molar ratios of $0.9,1.13,1.35$ and 1.55 , keeping the Si/Al molar ratio constant at about 1.69.

The resulting slurry was cast in stainless steel reusable molds to set at room temperature. After $20 \mathrm{hrs}$ from casting, the samples were then demolded and subjected to water curing at temperatures of $25^{\circ}$ (room temperature) and $80^{\circ} \mathrm{C}$ for up to 28 days. Depending on the XRD of one day curing at room temperature, mix 3 (Table 1) was also subjected to conventional hydrothermal curing (saturated steam curing) for up to $48 \mathrm{hr}$ at temperatures of $150{ }^{\circ} \mathrm{C}$ and $180^{\circ} \mathrm{C}$. After each curing period, the hydration 
TABLE 1. Mix compositions of metakaolin- K- based geopolymer samples in addition to curing conditions

\begin{tabular}{|c|c|c|c|c|c|c|c|c|}
\hline \multirow[b]{2}{*}{ Mixes } & \multicolumn{2}{|c|}{ Powder composition, wt. \% } & \multicolumn{2}{|l|}{ Additions, wt. $\%$} & \multirow{2}{*}{$\begin{array}{l}\text { K/Al, molar } \\
\text { ratio }\end{array}$} & \multirow{2}{*}{$\begin{array}{l}\mathrm{Si} / \mathrm{Al} \text { molar } \\
\text { ratio }\end{array}$} & \multirow{2}{*}{\multicolumn{2}{|c|}{ Curing conditions }} \\
\hline & Metakaolin & Potassium silicate & Water of workability & KOH & & & & \\
\hline M 1 & & & & 15 & 0.9 & & & - \\
\hline M 2 & & & & 22.5 & 1.13 & & & - \\
\hline M 3 & 65 & 35 & 45 & 30 & 1.35 & 1.69 & $\begin{array}{l}\text { at room } \\
\text { temperature } \\
\text { and at } 80^{\circ} \mathrm{C}\end{array}$ & $\begin{array}{l}\text { Conventional } \\
\text { hydrothermal } \\
\text { curing at } 150^{\circ} \\
\text { and at } 180^{\circ} \mathrm{C}\end{array}$ \\
\hline M 4 & & & & 37.5 & 1.55 & & & - \\
\hline
\end{tabular}

reaction was stopped by soaking the sample in an organic solvent mixture of ethyl alcohol and acetone $(1: 1)$ for two hours followed by washing with diethyl ether and drying overnight at $80^{\circ} \mathrm{C}(9)$.

\subsection{Sample characterization}

The crystalline reaction products were identified by XRD, using a powdered sample. Powder XRD was carried out using PANalytical Empyrean XRD equipment with $\mathrm{Cu} \mathrm{K} \alpha$ radiation. The morphology and particle size of powdered samples was determined by transmission electron microscopy (TEM) (Model 2010, JEOL, Tokyo, Japan) operating at $200 \mathrm{Kv}$. For TEM observation, the powdered samples were well dispersed in water using ultrasonic treatment and deposition on copper TEM grids. Since geopolymers are typically X-ray amorphous, solid-state ${ }^{29} \mathrm{Si}$ and ${ }^{27} \mathrm{Al}$ MAS NMR spectroscopy was carried out at $11.7 \mathrm{~T}$ to study the $\mathrm{x}$-ray amorphous phases in the reacting system. The spectra were acquired using a Bruker Avance III 500 spectrometer operating at $\mathrm{a}^{27} \mathrm{Al}$ frequency of $130.24 \mathrm{MHz}$ and $\mathrm{a}{ }^{29} \mathrm{Si}$ frequency of $99.29 \mathrm{MHz}$. The ${ }^{27} \mathrm{Al}$ solid-state spectra were acquired using a $4 \mathrm{~mm}$ Doty MAS probe with a silicon nitride rotor spun at $10-12 \mathrm{kHz}$, a $1 \mu$ s pulse and a $1 \mathrm{~s}$ recycle time, the spectra referenced with respect to $\mathrm{Al}\left(\mathrm{H}_{2} \mathrm{O}\right)_{6}^{3+}$. The ${ }^{29} \mathrm{Si}$ spectra were acquired with a $5 \mathrm{~mm}$ Doty MAS probe and a zirconia rotor spun at $\sim 6 \mathrm{kHz}$. The excitation pulse for ${ }^{29} \mathrm{Si}$ was $7 \mu$ s with a recycle time of $30 \mathrm{~s}$ and the spectra were referenced with respect to tetramethylsilane (TMS).

\section{RESULTS AND DISCUSSION}

\subsection{X-ray diffraction (XRD)}

The prepared geopolymer samples were monitored by XRD at periods of 1,7 and 28 days after curing in water at 25 and $80{ }^{\circ} \mathrm{C}$. The XRD patterns of all samples cured at 25 and $80{ }^{\circ} \mathrm{C}$ up to 28 days showed only amorphous phases as shown in Figure 1 for samples aged at $25^{\circ}$ for one day and Fig. 2 for samples aged at 25 and $80^{\circ} \mathrm{C}$ for 28 days. The XRD results show that these curing conditions produce only amorphous phases even in samples cured at $80^{\circ} \mathrm{C}$ as evidenced by the amorphous background hump at around $28^{\circ} 2 \theta$ (Figures 1 and 2). The only crystalline phase present (quartz) detected was originally present in the starting metakaolin (Figure 1). The decreasing of intensity of quartz peaks with increasing the potassium content (M1:M4) as shown in Fig. 1 could be explained the increasing of gelation process of geopolymer reaction. These samples were also fired at $1000{ }^{\circ} \mathrm{C}$ for $2 \mathrm{hr}$ and their XRD traces (Figure 3)

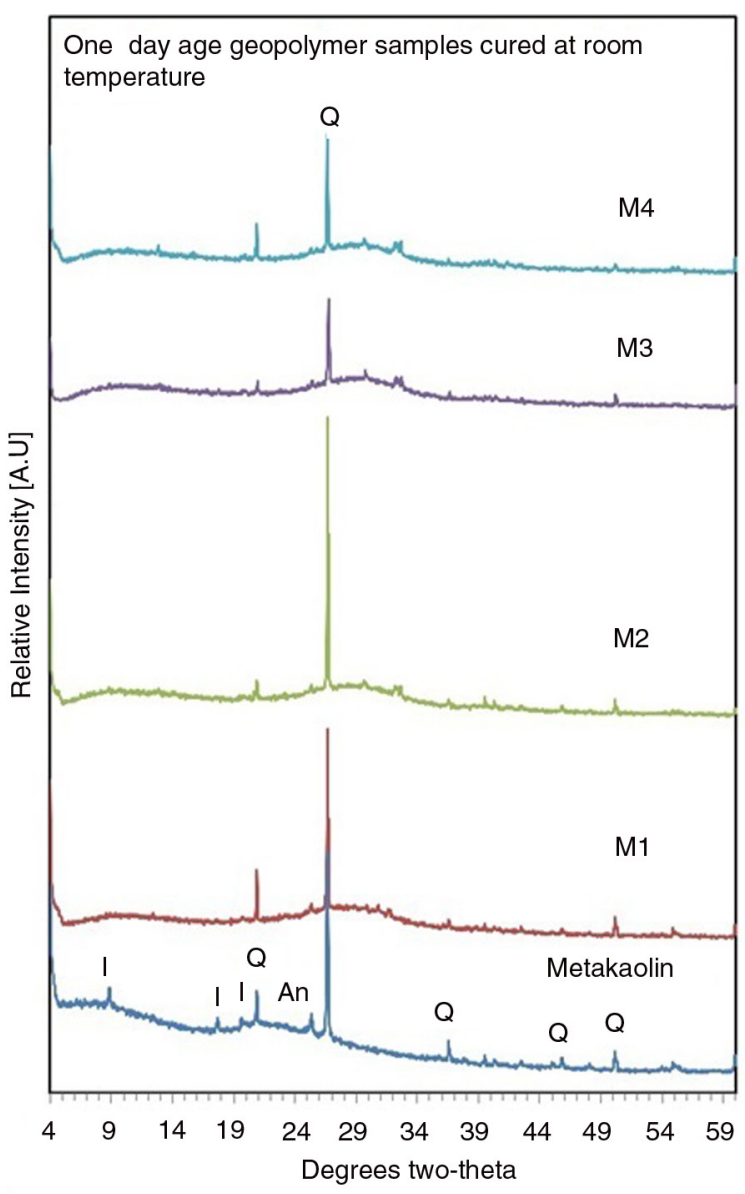

FIGURE 1. XRD traces of the geopolymers of different compositions cured for one day at room temperature compared with metakaolin as starting materials. Key:Q: Quartz - I: Illite - An: Anatase. 


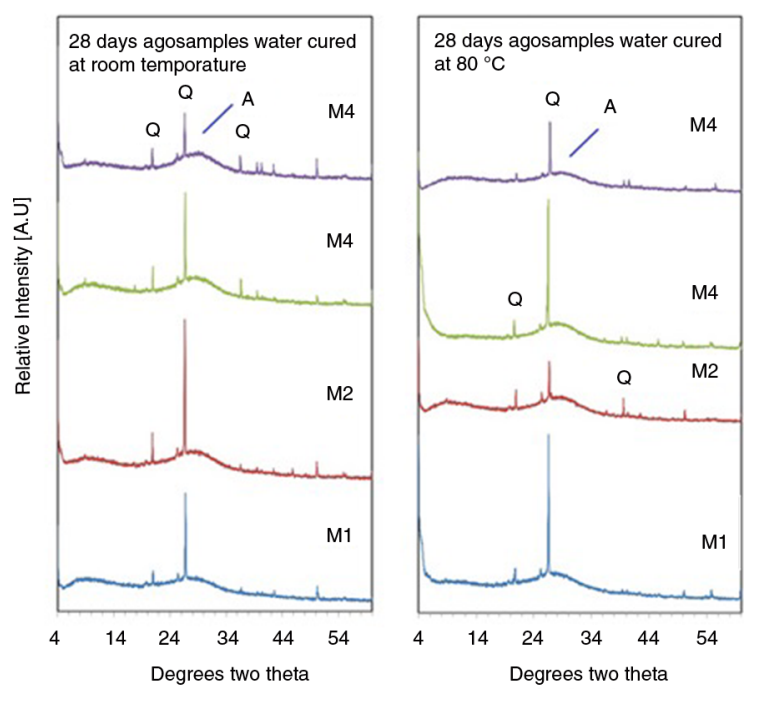

FIGURE 2. XRD traces of the geopolymers of different compositions cured in water for 28 days at $25^{\circ} \mathrm{C}$ and $80^{\circ} \mathrm{C}$. Key: $\mathrm{Q}=$ quartz, $\mathrm{A}=$ amorphous phase.

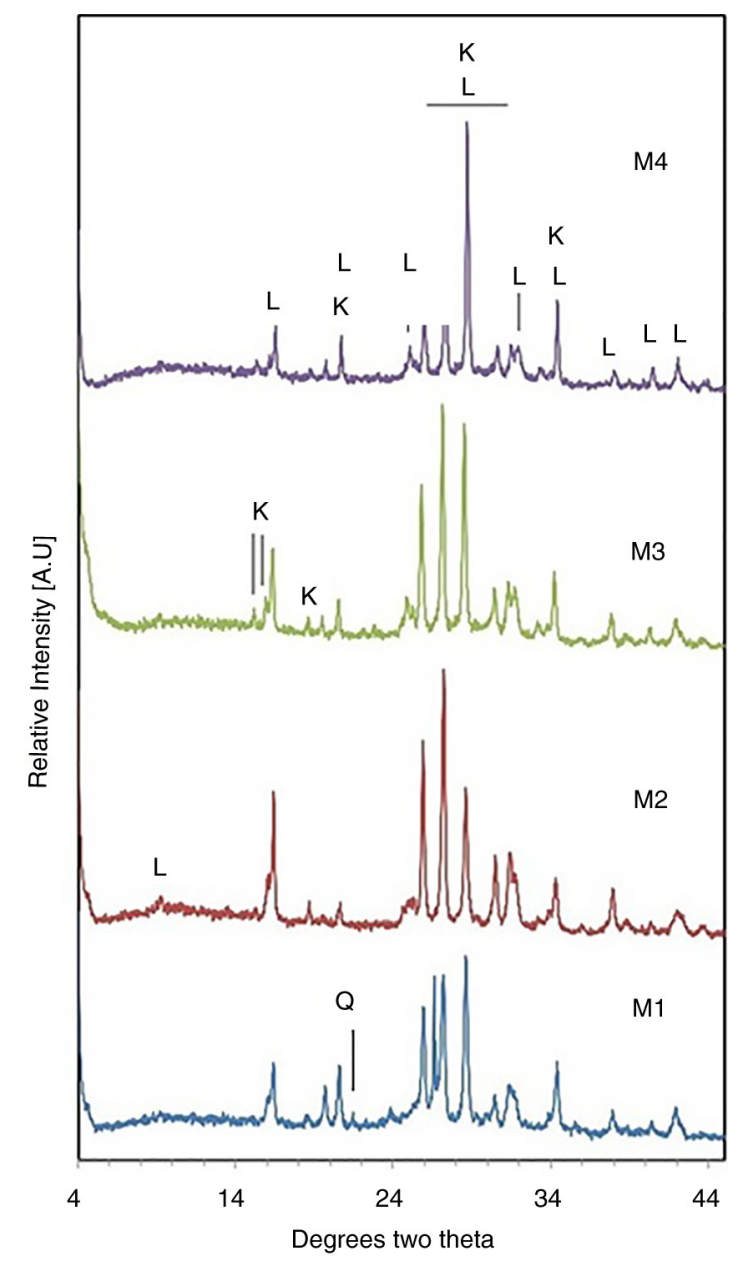

FIGURE 3. XRD traces of the geopolymers of different compositions after firing for $2 \mathrm{hr}$. at $1000^{\circ} \mathrm{C}$. Key: $\mathrm{K}=$ kalsilite, $\mathrm{KAlSiO}_{4}, \mathrm{~L}=$ leucite, $\mathrm{K}\left(\mathrm{AlSi}_{2} \mathrm{O}_{6}\right), \mathrm{Q}=\mathrm{Quartz}$. showed the formation of the crystalline potassium aluminosilicate phases leucite, $\mathrm{KAlSi}_{2} \mathrm{O}_{6}$ (PDF no. 1-76-8733) and kalsilite, $\mathrm{KAlSiO}_{4}$ (PDF no. 50-0436). These results are consistent with previously-reported studies $(10,11)$. A minor amount of unreacted quartz was also detected in sample no. 1.

The geopolymers prepared from mix no. 3 were monitored by XRD after periods of conventional hydrothermal curing for $6,12,24,30$ and $48 \mathrm{hr}$ at $150{ }^{\circ} \mathrm{C}$ and $180{ }^{\circ} \mathrm{C}$. The diffractograms (Figs. 4 and 5) show the typical amorphous hump in the XRD patterns at around $282 \theta^{\circ}$ even after curing at $150^{\circ} \mathrm{C}$ for up to $48 \mathrm{hr}$ (Figure 4), as is also the case for the samples cured at $180{ }^{\circ} \mathrm{C}$ for up to $30 \mathrm{hr}$ (Figure 5). However, the XRD trace of sample cured for $48 \mathrm{hr}$ at $180^{\circ} \mathrm{C}$ (Figure 4) contained the peaks of crystalline potassium aluminum silicate, $\mathrm{K}_{11.5}\left(\mathrm{Al}_{11.5} \mathrm{Si}_{20.5} \mathrm{O}_{64}\right)\left(\mathrm{H}_{2} \mathrm{O}\right)_{15.52}(\mathrm{PDF} \#$ 01-074-2934), and chabazite $\mathrm{K}, \mathrm{K}_{4.16}\left(\mathrm{Al}_{3.8} \mathrm{Si}_{8.2} \mathrm{O}_{24}\right)\left(\mathrm{H}_{2} \mathrm{O}\right)_{7.23}$ (PDF\# 01-085-0976), as well as quartz and minor amounts of anatase, the latter two being originally present in the metakaolin (Figure 1).

\subsection{Transmission electron microscopy (TEM)}

Selected samples were characterized by using TEM to investigate the morphology of the geopolymers. Figure 6 illustrated the TEM micrograph of

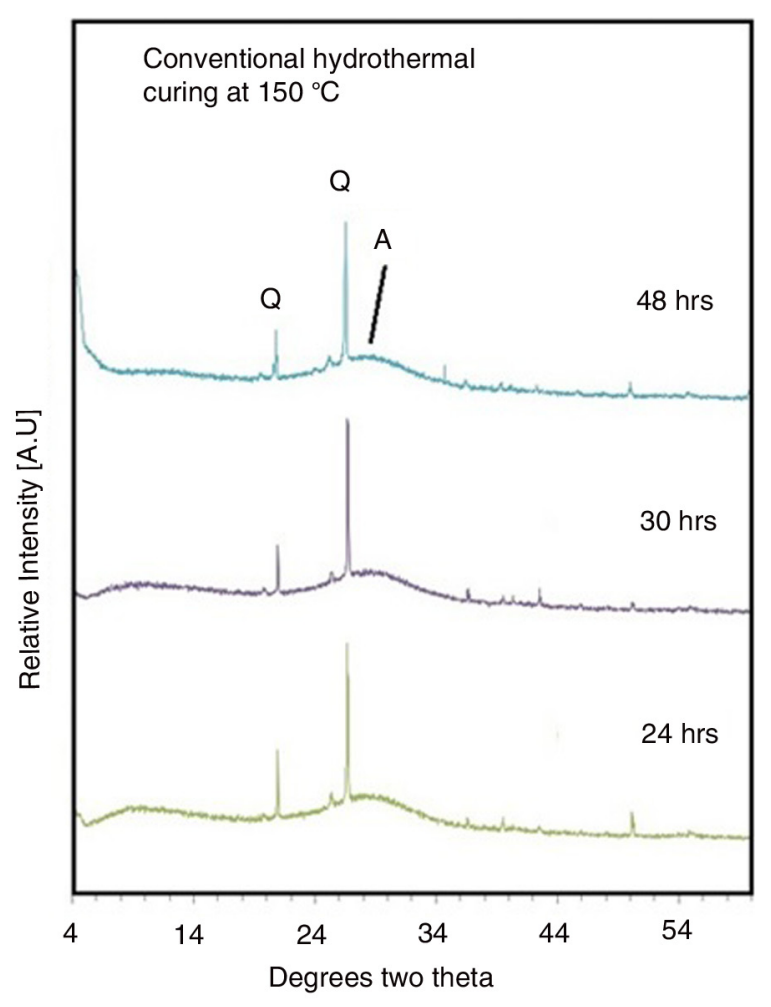

FIGURE 4. XRD traces of geopolymer samples cured hydrothermally at $150^{\circ} \mathrm{C}$ for up to $48 \mathrm{hr}$. Key: $\mathrm{Q}=$ quartz, $\mathrm{A}=$ amorphous phase. 


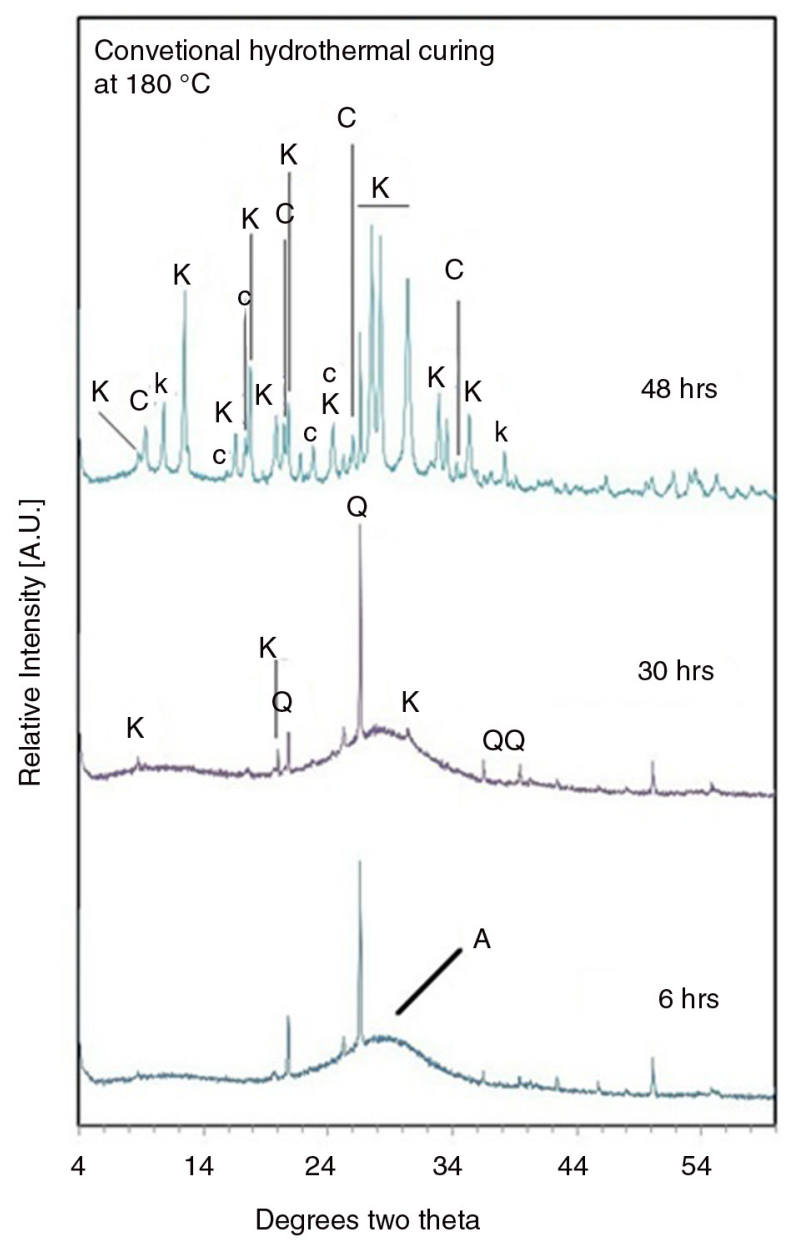

FiguRE 5. XRD traces of geopolymer samples cured at $180^{\circ} \mathrm{C}$ for periods up to $48 \mathrm{hrs}$. Key: $\mathrm{K}=$ potassium aluminum silicate, $\mathrm{K}_{11.5}\left(\mathrm{Al}_{11.5} \mathrm{Si}_{20.5} \mathrm{O}_{64}\right)\left(\mathrm{H}_{2} \mathrm{O}\right)_{15.52}, \mathrm{C}=$ chabazite, $\mathrm{K}, \mathrm{K}_{4.16}\left(\mathrm{Al}_{3.8} \mathrm{Si}_{8.2} \mathrm{O}_{24}\right)$ $\left(\mathrm{H}_{2} \mathrm{O}\right)_{7.23}, \mathrm{Q}=$ quartz, $\mathrm{A}=$ amorphous geopolymer phase. (a)

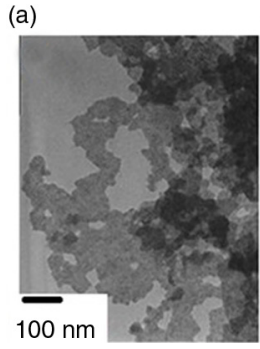

(b)

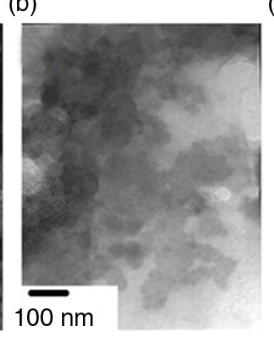

(a)

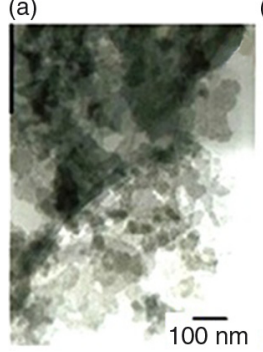

(b)

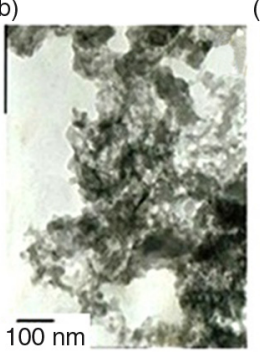

(c)

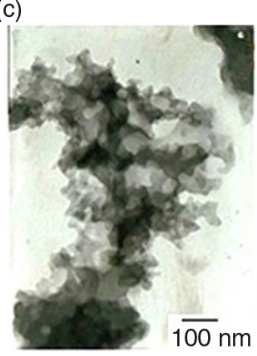

FIGURE 7. TEM micrographs of geopolymer samples prepared from mix M3, cured at room temperature and $80^{\circ} \mathrm{C}$ showing particle-like shapes: (a) cured for $7 \mathrm{~d}$ at room temperature, (b) cured for $7 \mathrm{~d}$ at $80^{\circ} \mathrm{C}$, (c) cured for $28 \mathrm{~d}$ at $80^{\circ} \mathrm{C}$. (a)

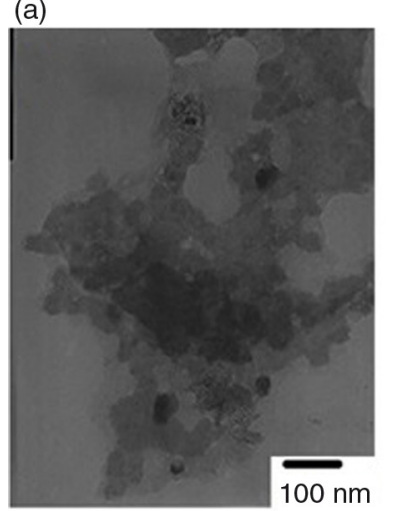

(c)

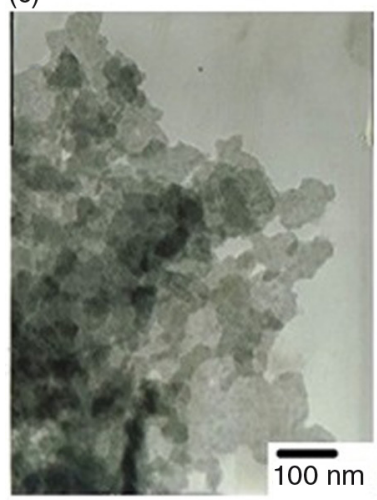

(b)

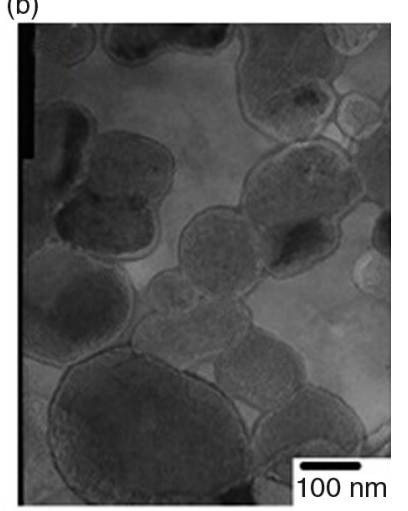

(d)

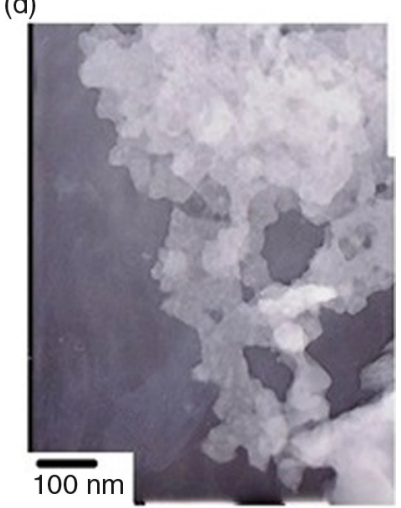

FIGURE 8. TEM micrographs of the geopolymer sample prepared from Mix 3 steam cured at $150^{\circ} \mathrm{C}$ for periods of (a) $6 \mathrm{hrs}$, (b) $12 \mathrm{hrs}$, (c) $24 \mathrm{hrs}$ and (d) $30 \mathrm{hrs}$.

in the geopolymer appears to have increased in mix 3 when cured at $80^{\circ} \mathrm{C}$ for 28 days compared with those cured at $80{ }^{\circ} \mathrm{C}$ for 7 days, evidenced by the appearance of particle-like shapes instead of the gel-like structures (Figure $7 \mathrm{a}-\mathrm{c}$ ).

The TEM micrographs of the samples cured by the conventional hydrothermal procedure for different periods at $150^{\circ} \mathrm{C}$ show that increasing the curing time from 6 to $30 \mathrm{hr}$ changes the morphology, increasing the appearance of amorphous particles with well-defined shapes as shown in Figure 8a-d. 
(a)

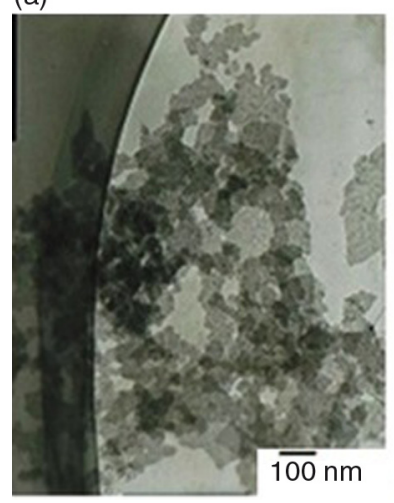

(b)

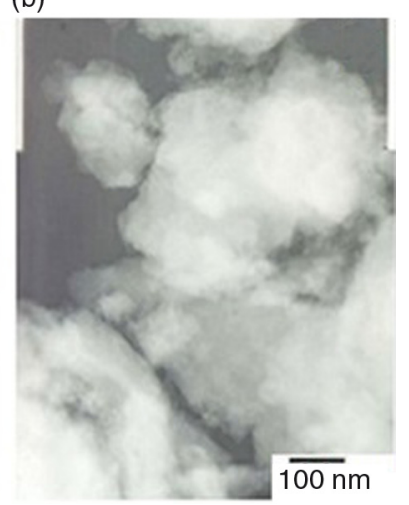

FIGURE 9. TEM micrographs of the geopolymer sample prepared from Mix 3 (a) hydrothermally cured at $150^{\circ} \mathrm{C}$ for $48 \mathrm{hr}$, (b) hydrothermally cured at $180^{\circ} \mathrm{C}$ for $48 \mathrm{hr}$.

Powder XRD of these samples (Figure 4) shows them all to retain the amorphous geopolymer characteristics, apart from the quartz originally present. On other hand, XRD of the sample steam cured for $48 \mathrm{hr}$ at $180{ }^{\circ} \mathrm{C}$ (Figure 5) indicates the formation of crystalline phases but the TEM micrographs (Figure 9b) show somewhat similar morphology to that of the X-ray amorphous sample cured at $150{ }^{\circ} \mathrm{C}$ for $30 \mathrm{hr}$ (Figure $8 \mathrm{~d}$ ). The similarity in the morphology of these samples suggested that an NMR investigation of the $\mathrm{Si}$ and $\mathrm{Al}$ atomic environments might yield further information about this apparently anomalous curing behavior.

\subsection{Solid-state MAS NMR spectroscopy}

\subsection{1. ${ }^{29}$ Si MAS NMR}

In geopolymers derived from metakaolin, the $\mathrm{Si}$ and $\mathrm{Al}$ atoms are in tetrahedral coordination as in the case of zeolites, with which they have structural similarities, containing a $\mathrm{Q}^{4}$ structure with four bridging oxygens (12). The broad major resonance in all the present samples cured under different conditions (Figs. 10,11) located at about -89 to $-95 \mathrm{ppm}$ is typical of the $\mathrm{Q}^{4}(3 \mathrm{Al})$ structure occurring in geopolymers (12). The broadness of this resonance arises from an envelope of slightly different sites and is typical of a non-crystalline structure. Some of the samples cured in water at room temperature (Figure 10) show an additional shoulder at about $-105 \mathrm{ppm}$, especially in samples synthesized with the two lowest potassium contents (mixes M1 and M2) (Figure 10). These shoulders are in the region of the $\mathrm{Q}^{4}(4 \mathrm{Si})$ environment (13), and suggest a less-complete reaction of the silica in these lower-alkali samples. The same resonance, associated with the crystalline quartz impurity in the original metakaolin, is more clearly visible at -108 to $-114 \mathrm{ppm}$ in the sample $\mathrm{M} 3$ cured in steam at $150^{\circ} \mathrm{C}$

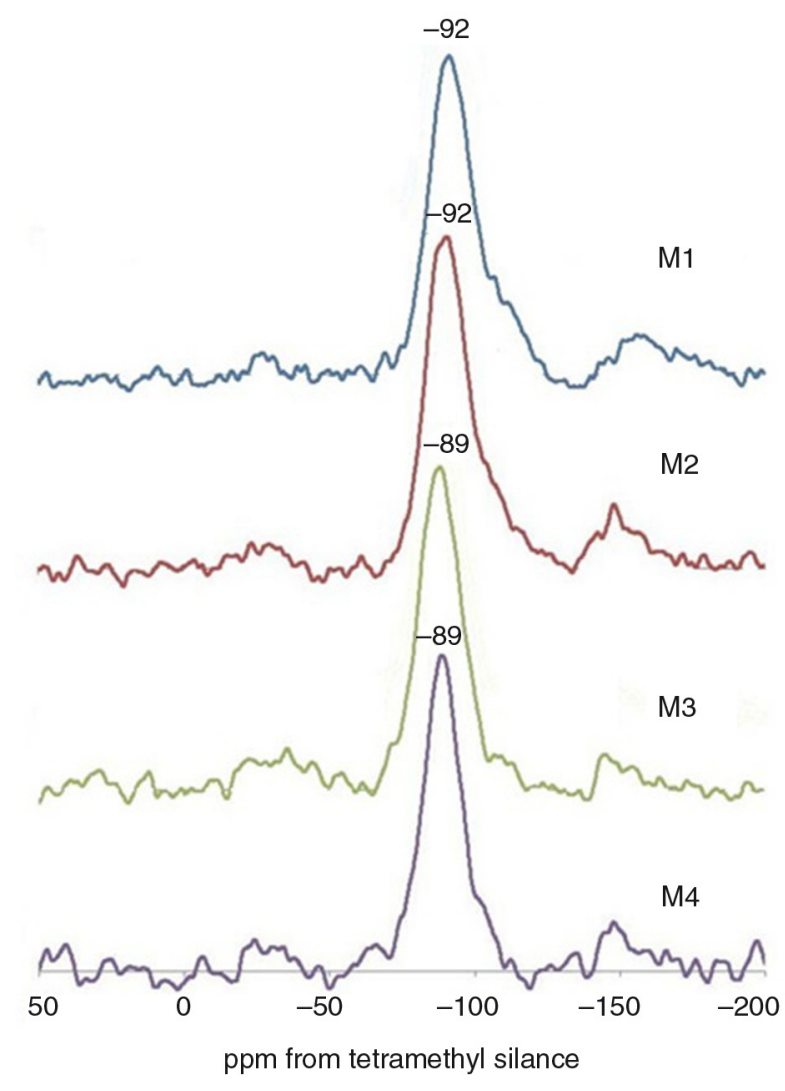

FIGURE 10. ${ }^{29} \mathrm{Si}$ MAS NMR of geopolymers cured in water at room temperature. The small peaks at about -25 and -160 ppm are spinning side bands.

for $48 \mathrm{hr}$ (Figure 11), as a result of the narrower envelope shape of the major resonance at $-90 \mathrm{ppm}$. This narrower envelope also reveals the presence of another component at $-99 \mathrm{ppm}$ in this spectrum, in the spectral region of $\mathrm{Si}-\mathrm{OH}$ groups (13), consistent with the curing of this sample in steam. The resonances of crystalline silica and $\mathrm{Si}-\mathrm{OH}$ groups are completely absent from the same sample more fully reacted at $180{ }^{\circ} \mathrm{C}$ for $48 \mathrm{hr}$ (Figure 11), suggesting that the formation of the crystalline aluminosilicate phases under these reaction conditions has consumed the additional silica originally present.

\subsection{2. ${ }^{27} \mathrm{Al} \mathrm{MAS} \mathrm{NMR}$}

The ${ }^{27} \mathrm{Al}$ NMR spectra, of all the samples with composition of (M1:M4) water cured at room temperature for 28 as well as the samples steam cured (with composition of M3) for different periods at $150^{\circ}$ and $180^{\circ} \mathrm{C}$, contain only one major resonance located at $\sim 57 \mathrm{ppm}$ corresponding to $\mathrm{Al}$ in a tetrahedral environment with an $\mathrm{AlQ}_{4}(4 \mathrm{Si})$ structure as shown in a ${ }^{27} \mathrm{Al}$ NMR representative graph for all samples of Figure 12 (13). The position of this resonance is typical of well-formed geopolymers (12), and the absence of resonances related to 6 -fold and 5-fold 


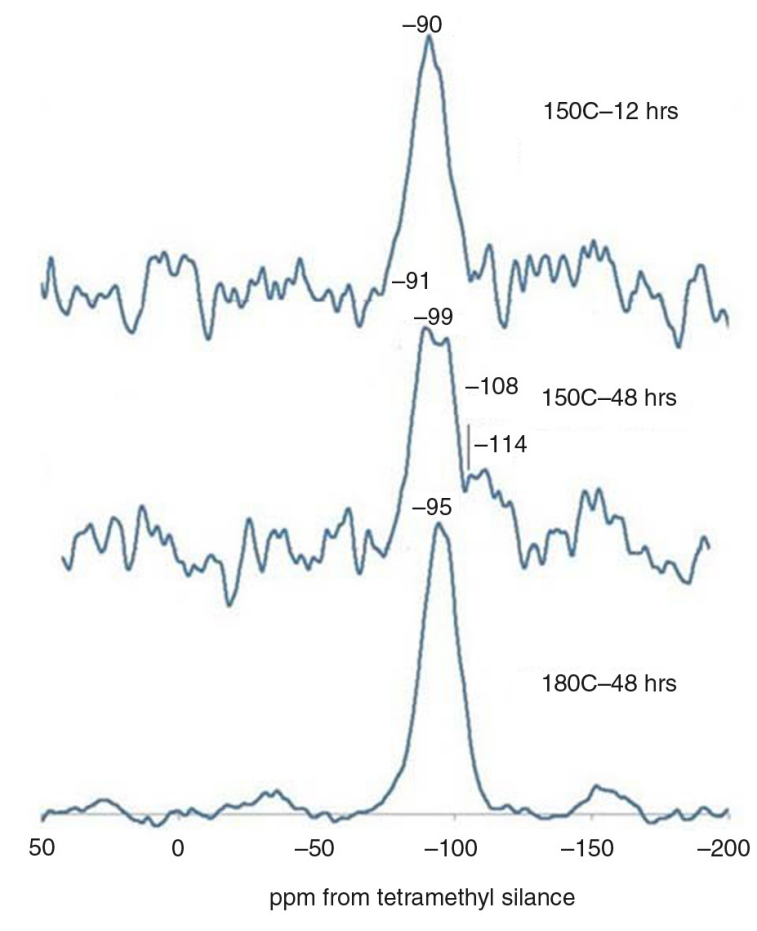

FIGURE 11. ${ }^{29}$ Si MAS NMR spectra of geopolymer sample M3 steam-cured at $150{ }^{\circ} \mathrm{Cand} 180^{\circ} \mathrm{C}$. The small peaks at about -25 and $-160 \mathrm{ppm}$ are spinning side bands.

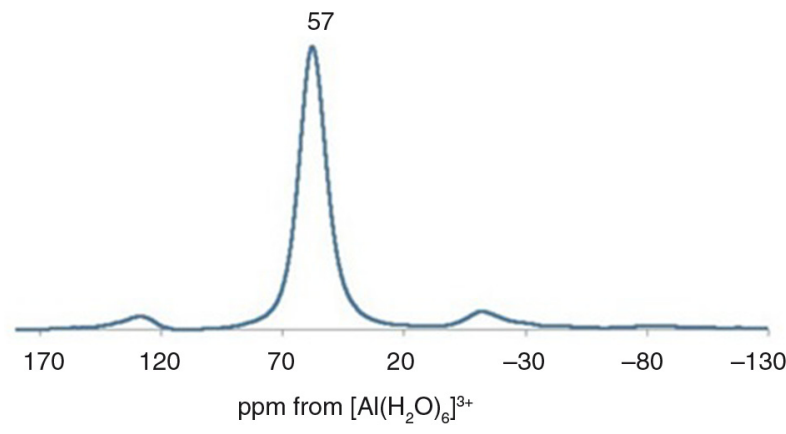

Figure 12. Representative ${ }^{27} \mathrm{Al}$ MAS NMR spectrum of geopolymers cured at room temperature, $80^{\circ} \mathrm{C}$, steam-cured at $150^{\circ} \mathrm{C}$ and $180^{\circ} \mathrm{C}$. The small peaks at about 130 and $-15 \mathrm{ppm}$ are spinning side bands.

coordinated $\mathrm{Al}$ at about 0 and $30 \mathrm{ppm}$ respectively (13) also confirms the complete consumption of a reactive part in metakaolin starting material in the geopolymer-forming reaction. The $\mathrm{Al}$ coordination is unaffected by the $\mathrm{K} / \mathrm{Al}$ ratio changed in composition from M1 to M4 of the geopolymer mixes or the geopolymer curing temperatures of $150^{\circ}$ and $180^{\circ} \mathrm{C}$.

\section{CONCLUSIONS}

Geopolymers derived from metakaolin and alkaline $\mathrm{K}$ solutions cured at room temperature or $80^{\circ} \mathrm{C}$, or steam-cured at $150{ }^{\circ} \mathrm{C}$ for $48 \mathrm{hr}$ and at $180{ }^{\circ} \mathrm{C}$ for $30 \mathrm{hr}$ remain X-ray amorphous. Their atomic environments are shown by ${ }^{27} \mathrm{Al}$ and ${ }^{29} \mathrm{Si}$ MAS NMR spectroscopy to be solely tetrahedral, consistent with completely-reacted geopolymers. When calcined at $1000{ }^{\circ} \mathrm{C}$ in air these geopolymers are shown by XRD to form the expected potassium aluminosilicate phases leucite, $\mathrm{KAlSi}_{2} \mathrm{O}_{6}$ and kalisilite, $\mathrm{KAlSiO}_{4}$.

Steam-curing these geopolymers at $180{ }^{\circ} \mathrm{C}$ for $48 \mathrm{hr}$ under hydrothermal conditions is shown by XRD to produce crystalline potassium aluminum silicate and chabazite. A corresponding change in the crystalline morphology is not observable by TEM, but the ${ }^{27} \mathrm{Al}$ and ${ }^{29} \mathrm{Si}$ MAS NMR spectra are narrower, consistent with a more crystalline structure, and the ${ }^{29} \mathrm{Si}$ spectrum indicates the formation of the crystalline aluminosilicates is accompanied by the consumption of some of the quartz impurity present in the original metakaolin.

\section{ACKNOWLEDGMENTS}

The authors acknowledge funding for this research from United States Agency of International Developments (USAID). The MAS NMR spectroscopy was financially supported by the MacDiarmid Institute for Advanced Materials and Nanotechnology.

\section{REFERENCES}

1. Gao, X.X.; Michaud, P.; Joussein, E.; Rossignol, S. (2013) Behavior of metakaolin-based potassium geopolymers in acidic solutions. J. Non-Cryst. Solids 380, 95-102. http:// dx.doi.org/10.1016/j.jnoncrysol.2013.09.002.

2. Duxson, P.; Provis, J.L.; Lukey, G.C.; Mallicoat, S.W. Kriven, W.M.; Van Deventer, J.S.J. (2005) Understanding the relationship between geopolymer composition, microstructure and mechanical properties. Colloids Surf., A 269 [1-3], 47-58. http://dx.doi.org/10.1016/j.colsurfa.2005.06.060.

3. Steveson, M.; Sagoe-Crentsil, K. (2005) Relationships between composition, structure and strength of inorganic polymers. Part I. Metakaolin-derived inorganic polymers. Mater. Sci. 40 [8], 2023-2036. http://dx.doi.org/10.1007/ s10853-005-1226-2.

4. Weng, L.; Sagoe-Crentsil, K. (2007) Dissolution processes, hydrolysis and condensation reactions during geopolymer synthesis. Part I. Low Si/Al ratio systems. Mater. Sci. 42 [9], 2997-3006. http://dx.doi.org/10.1007/s10853-006-0820-2.

5. Duxson, P.; Fernandez-Jimenez, A.; Provis, J.L.; Lukey, G.C.; Palomo, A.; Van Deventer, J.S.J. (2007) Geopolymer technology: the current state of the art. J. Mater. Sci. 42 [9], 2917-2933. http://dx.doi.org/10.1007/s10853-006-0637-z.

6. Mu-iz-Villarreal, M.S.; Manzano-Ramírez, A.; SampieriBulbarela, S.; Ramón Gasca-Tirado, J.; Reyes-Araiza, J.L.; Rubio-Ávalos, J.C.; Pérez-Bueno, J.J.; Apatiga, L.M.; Zaldivar-Cadena, A; Amigó-Borrás, V. (2011) The effect of temperature on the geopolymerization process of a metakaolin-based geopolymer. Mater. Lett. 65 [6], 995-998. http:// dx.doi.org/10.1016/j.matlet.2010.12.049.

7. Mustafa Al Bakria, A.M.; Kamarudina, H.; Bin Hussain, M.; Khairul Nizar, I.; Zarina, Y.; Rafiza, A.R. (2011) The effect of curing temperature on physical and chemical properties of geopolymers. Phys. Procedia 22, 286-291. http:// dx.doi.org/10.1016/j.phpro.2011.11.045.

8. Lancellotti, I.; Catauro, M.; Ponzoni, C.; Bollino, F.; Leonelli, C. (2013) Inorganic polymers from alkali activation of metakaolin: Effect of setting and curing on structure. J. Solid State Chem. 200, 341-348. http://dx.doi.org/10.1016/j. jssc.2013.02.003. 
9. Khater, H.M. (2013) Effect of silica fume on the characterization of the geopolymer materials. Int. j. adv. struct. eng. 5, 12. http://dx.doi.org/10.1186/2008-6695-5-12.

10. Barbosa V.F.F., MacKenzie K.J.D. (2003) Synthesis and thermal behavior of potassium sialategeopolymers. Mater. Lett. 57 [9-10], 1477-82. http://dx.doi.org/10.1016/S0167$577 \mathrm{X}(02) 01009-1$

11. White, C.L.; Provis, J.L.; Proffen, T.; Van Deventer, J.S.J. (2010) The effects of temperature on the local structure of metakaolin-based geopolymer binder: a neutron pair distribution function investigation. J. Am. Ceram. Soc.
93 [10], 3486-3492. http://dx.doi.org/10.1111/j.1551-2916. 2010.03906.x

12. Barbosa, V.F.F.; MacKenzie, K.J.D.; Thaumaturgo, C. (2000) Synthesis and Characterization of Materials Based on Inorganic Polymers of Alumina and Silica: Sodium Polysialate Polymers. Int. J. Inorg. Mater. 2, 309-317. http:// dx.doi.org/10.1016/S1466-6049(00)00041-6.

13. MacKenzie, K.J.D.; Smith, M.E. (2002) Multinuclear Solid State NMR of Inorganic Materials, Pergamon Materials Series Vol. 6, Pergamon/Elsevier, Oxford. 